\title{
Pemberdayaan Masyarakat dan Keluarga melalui Pemberian Pendidikan Kesehatan dalam Merawat Anggota Keluarga dengan Gangguan Jiwa
}

\author{
Mila Triana Sari ${ }^{1}$, Daryanto ${ }^{2}$ \\ Program Studi Profesi Ners STIKes Baiturrahim Jambi \\ Jurusan Keperawatan, Poltekkes Kemenkes Jambi \\ email: milatrianasari73@gmail.com
}

Submitted : 04/10/12/2021

Accepted: 19/10/2021

Published: 19/11/2021

\begin{abstract}
Mental health is still a significant health problem in the world, including in Indonesia. The results of the 2018 Basic Health Research show the prevalence of severe mental disorders, such as schizophrenia, is 1.7 per 1000 population or around 400,000 people. This condition needs serious attention from all levels of cross-sectoral government both at the Central and Regional levels, as well as attention from the entire community, especially families. The lack of understanding of the community and families about how to treat People with Mental Ilness (PwMI) will have a nonoptimal impact on the recovery of family members who suffer from mental disorders. The purpose of this community service is to increase the knowledge and ability of the community and family as an effort to achieve community and family independence in caring for (PWMI). The activities carried out were in the form of socialization, pre-test, health education using power points and leaflets, demonstration of how to care for (PWMI), post test and assistance to families of (PWMI). The activity was attended by village officials, health workers, community leaders, cadres and families with (PWMI). The result of this activity was an increase in the knowledge and ability of the community and family in caring for (PWMI) with a difference of $27.5 \%$ in the pre and post test scores. The conclusion is that providing health education to families and communities is effective in increasing knowledge and ability in caring for (PWMI), it is hoped that this service activity can provide information, knowledge and motivation to the community and families about how to care for (PWMI), so that it will encourage (PWMI) to live independently, productively, and confidently. in the community, free from stigma, discrimination or fear, shame and doubt also reduce the risk of recurrence in (PWMI).
\end{abstract}

Keywords: empowerment, community, family, health education, people with mental disorder

\begin{abstract}
Abstrak
Kesehatan jiwa masih menjadi salah satu permasalahan kesehatan yang signifikan di dunia, termasuk di Indonesia. Hasil Riset Kesehatan Dasar (Riskesdas) tahun 2018, menunjukkan prevalensi gangguan jiwa berat, seperti schizophrenia adalah 1,7 per 1000 penduduk atau sekitar 400.000 orang. Kondisi ini perlu mendapat perhatian yang sungguh-sungguh dari seluruh jajaran lintas sektor Pemerintah baik di tingkat Pusat maupun Daerah, serta perhatian dari seluruh masyarakat, khususnya keluarga. Kurangnya pemahaman masyarakat dan keluarga tentang bagaimana cara merawat (ODGJ) akan memberi dampak tidak optimal kepada kesembuhan anggota keluarga yang menderita gangguan jiwa. Tujuan pengabdian masyarakat ini adalah untuk meningkatkan pengetahuan dan kemampuan masyarakat dan keluarga sebagai upaya mencapai kemandirian masyarakat dan keluarga merawat (ODGJ). Adapun kegiatan yang dilakukan berupa sosialisasi, pre test, pendidikan kesehatan menggunakan power point dan leaflet, demonstrasi cara merawat (ODGJ), post test serta pendampingan pada keluarga (ODGJ). Kegiatan diikuti oleh perangkat desa, petugas kesehatan, tokoh masyarakat, kader dan keluarga dengan (ODGJ). Hasil kegiatan ini terjadi peningkatan pengetahuan dan kemampuan masyarakat dan keluarga dalam merawat (ODGJ) dengan selisih nilai pre dan post test sebesar $27,5 \%$. Simpulan pemberian pendidikan kesehatan kepada keluarga dan masyarakat efektif untuk meningkatkan pengetahuan
\end{abstract}


dan kemampuan dalam merawat (ODGJ), diharapkan kegiatan pengabdian ini dapat memberikan informasi pengetahuan dan motivasi kepada masyarakat dan keluarga tentang cara merawat (ODGJ), sehingga akan mendorong (ODGJ) dapat hidup mandiri, produktif, dan percaya diri di tengah masyarakat, bebas dari stigma, diskriminasi atau rasa takut, malu dan ragu-ragu serta mengurangi resiko kekambuhan pada (ODGJ).

Kata Kunci: keluarga, masyarakat, orang dengan gangguan jiwa, pemberdayaan, pendidikan kesehatan,

\section{PENDAHULUAN}

Kesehatan jiwa masih menjadi salah satu permasalahan kesehatan yang signifikan di dunia, termasuk di Indonesia. Menurut data WHO (2016) dalam Kemenkes (2016) terdapat sekitar 35 juta orang terkena depresi, 60 juta orang terkena bipolar, 21 juta terkena skizofrenia, serta 47,5 juta terkena dimensia. Beban penyakit atau burden of disease penyakit jiwa di Tanah Air masih cukup besar. Hasil Riset Kesehatan Dasar (Riskesdas) tahun 2018, menunjukkan bahwa prevalensi gangguan jiwa berat, seperti schizophrenia adalah 1,7 per 1000 penduduk atau sekitar 400.000 orang.

Skizofrenia merupakan suatu gangguan umum pada penduduk dunia. Skizofrenia adalah gangguan mental yang menyebabkan seseorang menjadi disfungsional secara fisiologis untuk dirinya sendiri maupun interaksi secara sosial (Prabowo, 2014). Berdasarkan hasil Riskesdas (2018) menunjukkan bahawa angka skizofrenia paling tinggi di Bali $11 \%$ dan terendah di Kepulauan Riau 3\%, sedangkan untuk Provinsi Jambi saat ini menempati urutan ke 21 dengan 5,2\%.

Masalah kesehatan jiwa di Indonesia merupakan masalah kesehatan masyarakat yang sangat penting dan harus mendapat perhatian sungguh-sungguh dari seluruh jajaran lintas sektor Pemerintah baik di tingkat Pusat maupun Daerah, ini sesuai dengan Undang-undang no 18 tahun 2014 tentang kesehatan jiwa, yang menyatakan Upaya Kesehatan Jiwa adalah setiap kegiatan untuk mewujudkan derajat kesehatan jiwa yang optimal bagi setiap individu, keluarga, dan masyarakat dengan pendekatan promotif, preventif, kuratif, dan rehabilitatif yang diselenggarakan secara menyeluruh, terpadu, dan berkesinambungan oleh Pemerintah, Pemerintah Daerah, dan/atau masyarakat.

Disamping itu, upaya lain yang tidak kalah pentingnya adalah pemberdayaan masyarakat dalam perawatan ODGJ, akan mendorong ODGJ dapat hidup mandiri, produktif, dan percaya diri di tengah masyarakat, bebas dari stigma, diskriminasi atau rasa takut, malu serta ragu-ragu. Upaya ini sangat ditentukan oleh kepedulian keluarga dan masyarakat di sekitarnya serta perhatian dari seluruh masyarakat, khususnya keluarga. Pemberdayaan keluarga sangat diperlukan sesuai dengan lima tugas kesehatan keluarga, yaitu mengenal masalah gangguan jiwa, memutuskan untuk merawat, melakukan perawatan, memodifikasi lingkungan dalam perawatan anggota keluarga dengan ODGJ dan memanfaatkan pelayanan kesehatan untuk pengobatan gangguan jiwa, (Friedman, 2010)

Hasil penelitian Daryanto (2017) menemukan sekitar $45 \%$ keluarga penderita Skizofrenia mengalami Stigma Berat dari masyarakat. Hal ini akan berpengaruh terhadap dukungan yang diberikan kepada . Lebih lanjut Daryanto dan Khairani (2018) menemukan sekitar 46,1 sampai 58,3\% penderita Skizofrenia mengalami Stigma diri yang berat sampai sangat berat. Hal ini menggambarkan bahwa keluarga dan pasien sering mengalami stigma atau mendapat cap atau lebel negative dari masyarakat maupun dari diri sendiri. Kondisi ini bila dibiarkan akan memperburuk proses pemulihan ODGJ. 
Salah satu peran perawat adalah sebagai pendidik klien. Perawat sebagai tenaga kesehatan di masyarakat memiliki peran memberikan pendidikan kesehatan terkait masalah yang dihadapi masyarakat dan keluarga. Peran ini penting dijalankan sebagai bagian membantu keluarga dan masyarakat agar mandiri dalam mengatasi masalah kesehatannya. Melalui pendidikan kesehatan diharapkan terjadi perubahan perilaku keluarga dan masyarakat terhadap orang dengan gangguan jiwa seperti skizofrenia sehingga dapat memberikan dukungan secara positif dan mencegah perlakuan berupa stigma yang masih berlangsung di masyarakat. Disamping itu keluarga diharapkan selain menjadi sistem pendukung ODGJ juga sekaligus mampu merawat ODGJ di rumah, melakukan resosialisasi dan pencegahan kekambuhan.

$$
\text { Hasil wawancara dengan }
$$

penanggungjawab kegiatan pembinaan kesehatan masyarakat Puskesmas Penyengat Olak, diperoleh informasi bahwa di Desa Penyengat Olak terdapat 36 orang kader kesehatan yang terintegrasi untuk posyandu balita dan posbindu. Kader yang ada belum pernah mendapatkan informasi terkait pencegahan stigma, dan dukungan bagi orang dengan gangguan jiwa. Disamping itu jumlah orang dengan gangguan jiwa di Desa Penyengat olak berjumlah 24 orang. Hasil wawancara dengan Sekretaris Desa, belum ada kegiatan penyuluhan atau pendidikan kesehatan terhadap pencegahan Stigma, dukungan keluarga dan cara merawat orang dengan gangguan jiwa. Menurut Sekretaris Desa kegiatan ini penting karena keluarga umumnya kewalahan cara mengurus anggota keluarganya yang sakit jiwa. Keluarga pasien dan masyarakat dalam kondisi saat ini seyogyanya mendapatkan perhatian khusus tentang cara pencegahan stigma, dukungan keluarga dan masyarakat serta cara merawat orang dengan gangguan jiwa. Hanya saja keterbatasan sumber informasi baik dari petugas kesehatan, tokoh masyarakat ataupun media lainnya membuat mereka masih perlu mendapatkan bimbingan untuk menerapkan perawatan pada orang dengan gangguan jiwa.

Berdasarkan paparan diatas, sebagai bentuk pengabdian kepada masyarakat, maka tim PKM Stikba ikut berkontribusi untuk meningkatkan pengetahuan dan kemampuan masyarakat dan keluarga dengan memberikan pendidikan kesehatan bagaimana pencegahan stigma dari masyarakat terhadap penderita dan keluarga dengan gangguan jiwa, dukungan masyarakat dan keluarga pada orang dengan gangguan jiwa serta cara perawatan orang dengan gangguan jiwa di rumah.

Secara rinci masalah yang dihadapi oleh mitra dapat dilihat pada uraian dibawah ini :

a. Sebagian besar masyarakat dan keluarga belum memahami tentang cara merawat orang dengan gangguan jiwa.

b. Belum maksimalnya dukungan keluarga terhadap anggota keluarga yang mengalami gangguan jiwa.

c. Masih tingginya stigma masyarakat terhadap orang dengan gangguan jiwa.

d. Belum optimalnya pendampingan keluarga tentang cara merawat orang dengan gangguan jiwa.

e. Petugas kesehatan dan kader menyampaikan perlunya dilaksanakan pendidikan kesehatan pada masyarakat dan keluarga dengan gangguan jiwa.

\section{TARGET DAN LUARAN}

Target yang dicapai pada Pengabdian kepada masyarakat ini adalah :

a. Pendidikan Kesehatan dan Sosialisasi tentang cara keluarga merawat orang dengan gangguan jiwa.

b. Pendampingan keluarga cara merawat orang dengan gangguan jiwa.

c. Sosialisasi terkait stigma dan dampak buruknya serta pencegahannya di masyarakat. 
d. Demonstrasi cara merawat orang dengan gangguan jiwa.

Luaran dari kegiatan Pengabdian masyarakat ini adalah :

a. Publikasi artikel pada jurnal pengabdian masyarakat (draft).

b. Tersedianya media KIE ( Leaflet dan Booklet ).

c. Terjadinya peningkatan pengetahuan masyarakat dan keluarga tentang cara merawat orang dengan gangguan jiwa dan mengurangi stigma pada orang dengan gangguan jiwa.

\section{METODE PELAKSANAAN}

Kegiatan pengabdian kepada masyarakat ini dilakukan di desa Penyengat Olak Kabupaten Muaro Jambi, dengan metode memberikan pendidikan kesehatan, demonstrasi, redemonstrasi, pre- post test dan pendampingan pada keluarga dalam merawat ODGJ. Metode ini sesuai dengan tujuannya yaitu memberikan peningkatan pengetahuan sehingga masyarakat dan keluarga memiliki persepsi yang sama terkait cara merawat ODGJ sebagai upaya meningkatkan kemandirian masyarakat dan keluarga dalam merawat ODGJ dan melakukan resosialisasi pada ODGJ dan pencegahan kekambuhan, termasuk mengurangi stigma masyarakat pada keluarga dengan anggota keluarga ODGJ.

Media yang digunakan dalam kegiatan ini adalah media visual yaitu slide Power Point (PPT). Media ini berguna untuk menstimulasi indra penglihatan pada saat dilangsungkannya pendidikan kesehatan. (Notoatmodjo, et.al, 2012). Kegiatan ini dilaksanakan pada bulan Juni Agustus 2021 dengan jumlah peserta 40 orang terdiri dari petugas kesehatan puskesmas Penyengat Olak, Kepala desa dan tokoh masyarakat Desa Penyengat Olak serta masyarakat dan keluarga ODGJ. Selain mitra dan pelaksana, kegiatan ini dibantu oleh beberapa orang mahasiswa Program SI Keperawatan Baiturrahim Jambi.

\section{Pelaksanaan Kegiatan}

Kegiatan pengabdian masyarakat ini dilaksanakan dengan beberapa tahapan yaitu: 1) Tahapan persiapan, pada tahap ini tim mengidentifikasi permasalahan yang terjadi pada masyarakat dan keluarga dengan ODGJ diwilayah kerja Puskesmas dan desa Penyengat Olak sehingga dapat memutuskan tema untuk pendidikan kesehatan yang dilakukan.

2) Tahapan pelaksanaan kegiatan yaitu Pre-Test, Penyampaian materi pendidikan kesehatan tentang perawatan orang dengan gangguan jiwa, diskusi, demonstrasi dan redemonstrasi tentang cara merawat ODGJ, Post-Test, serah terima leaflet, booklet, dan cendera hati, dan diakhiri dengan penutupan.

\section{Monitoring dan Evaluasi}

Monitoring dan evaluasi (Monev) dengan meminta feedback secara langsung terhadap kegiatan yang dilakukan, serta tahapan terakhir adalah penulisan laporan dan publikasi.

\section{HASIL DAN PEMBAHASAN}

Hasil kegiatan pengabdian kepada masyarakat yang telah dilaksanakan pada 40 masyarakat dan keluarga yang berpartisipasi di desa Penyengat Olak dengan tetap melaksanakan protokol kesehatan. Adapun rata-rata nilai pre-test sebesar 48,5\% meningkat menjadi 76,0\% pada saat post-test, (meningkat sebesar 27,5\%). Ini menunjukkan kegiatan pendidikan kesehatan yang dilakukan cukup efektif terhadap peningkatan pengetahuan dan pemahaman masyarakat dan keluarga. Saat dilaksanakan pendidikan kesehatan, masyarakat dan keluarga antusias, semangat dan memperhatikan materi yang disampaikan 
dari awal sampai akhir kegiatan, sehingga terjadi peningkatan pengetahuan sebelum dan sesudah diberikan pendidikan kesehatan.

Evaluasi kegiatan yang sudah dilakukan termasuk dalam kategori baik. Beberapa tujuan yang diharapkan sudah tercapai. Masyarakat dan keluarga mengetahui tentang dampak negatif stigma pada orang dengan gangguan jiwa, sehingga berupaya untuk mencegah bahkan memperkecil stigma pada ODGJ, adanya peningkatan pengetahuan masyarakat dan keluarga cara merawat ODGJ, serta meningkatkan motivasi dan dukungan masyarakat dan keluarga terhadap ODGJ.

Pendidikan kesehatan bertujuan untuk mengubah perilaku individu, keluarga, serta masyarakat dari prilaku tidak sehat menjadi prilaku sehat (Widyanto, 2014). Selain itu pendidikan kesehatan yang diberikan pada keluarga dapat menurunkan ansietas secara bermakna (Nurbani, 2009).

Kegiatan pengabdian masyarakat melalui pendidikan kesehatan pada masyarakat dan keluarga ini merupakan salah satu bentuk upaya kepedulian masyarakat dan keluarga terhadap ODGJ di desa Penyengat Olak, sekaligus sebagai komitmen pemberdayaan masyarakat dan keluarga dalam memampukan ODGJ sesuai UU no 18 tahun 2014 tentang kesehatan jiwa. Pemberdayaan masyarakat dan keluarga juga sebagai perpanjangan tangan petugas kesehatan dalam melakukan deteksi dini terhadap kesehatan jiwa dimasyarakat dan keluarga, sebelum dibawa ke pelayanan kesehatan terdekat.

Masyarakat dan keluarga sebagai sasaran pemberian psikoedukasi dalam perawatan kesehatan ODGJ akan berhasil dengan baik jika masyarakat dan keluarga memahami materi psikoedukasi yang diberikan, sehingga berdampak pada kemampuan dan kemandirian keluarga dan masyarakat dalam merawat ODGJ.
Peningkatan pengetahuan dan pemahaman masyarakat dan keluarga terkait cara merawat ODGJ dapat mendorong kesiapan masyarakat untuk dapat menerima ODGJ ditengah-tengah masyarakat dan keluarga dalam lingkungan yang kondusif, sehingga frekuensi kekambuhan ODGJ menjadi lebih kecil dan secara berangsur-angsur mengembalikan kualitas hidup ODGJ untuk menjadi individu yang produktif dan mandiri.

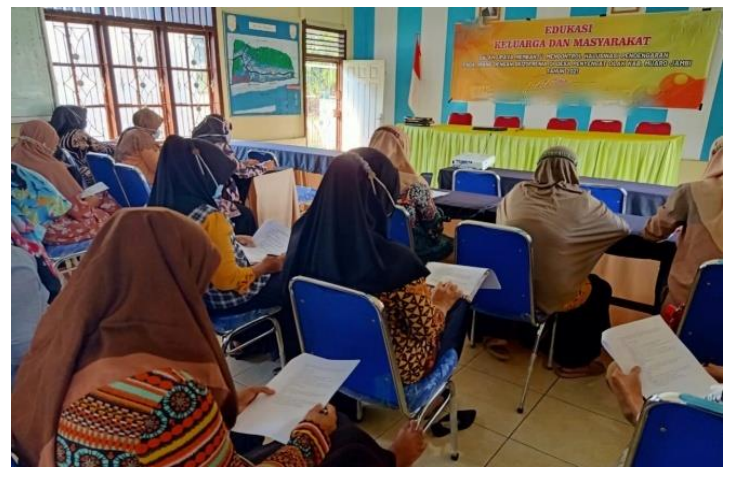

Gambar 1. Pelaksanaan Pre test

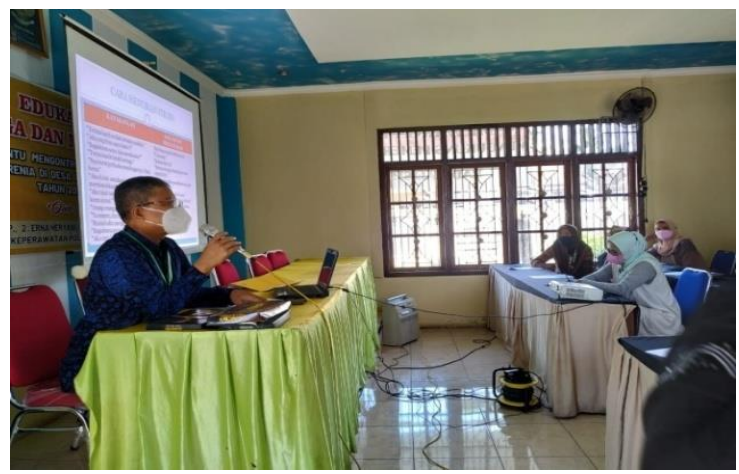

Gambar 2. Pemberian Materi

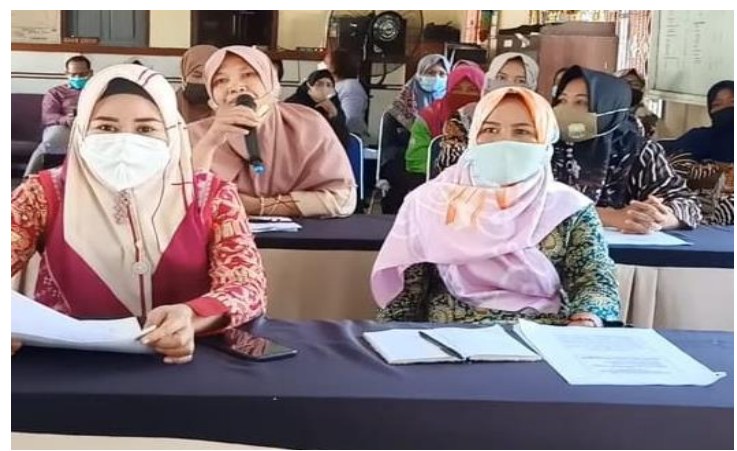

Gambar 3. Sesi Diskusi 


\section{KESIMPULAN DAN SARAN}

\section{Kesimpulan}

Kegiatan pengabdian masyarakat berupa pendidikan kesehatan dapat digunakan untuk meningkatkan pengetahuan dan kemampuan masyarakat dan keluarga terkait merawat ODGJ dengan selisih rata- rata nilai pre dan post test $27,5 \%$, pemahaman masyarakat terkait pentingnya dukungan keluarga terhadap ODGJ dan memperkecil stigma bila ada keluarga yang anggota keluarganya termasuk ODGJ. Kegiatan pengabdian masyarakat berjalan lancar dan mendapat dukungan dari pihak mitra baik dari tingkat dinas kesehatan, puskesmas, desa Penyengat Olak serta masyarakat dan keluarga.

\section{Saran}

Berdasarkan hasil pengabdian ini disarankan kepada Kepala desa dan perangkat desa Penyengat Olak melakukan kerjasama dengan pihak puskesmas bersama kader kesehatan jiwa untuk menyusun program kegiatan promotif dan peningkatan kesehatan yang berkelanjutan khususnya untuk pencegahan, pendeteksian dini, penanganan dan perawatan orang dengan gangguan jiwa di desa Penyengat Olak, serta menjadikan desa Penyengat Olak sebagai Desa Sehat Jiwa.

\section{UCAPAN TERIMA KASIH}

Semua tim dan mitra pada kegiatan pengabdian ini mengucapkan terima kasih kepada:

1. Kepala Dinas Kesehatan Kabupaten Muaro Jambi beserta jajarannya.

2. Kepala UPTD Puskesmas Penyengat Olak Kabupaten Muaro Jambi beserta jajarannya.

3. Kepala desa beserta perangkat desa Penyengat Olak

4. Ketua STIKes Baiturrahim Jambi beserta jajarannya.
5. Mahasiswa Program SI Keperawatan STIKes Baiturrahim Jambi.

6. Semua pihak yang membantu terlaksananya kegiatan ini.

\section{DAFTAR PUSTAKA}

Ahmad Kholid., Promosi Kesehatan dengan Pendekatan Teori Perilaku, Media dan aplikasinya., 2015. Jakarta; Rajawali Press

Kementrian Kesehatan Republik Indonesia. (2018). Riset Kesehatan Dasar. Jakarta Badan Penelitian dan Pengembangan Kesehatan Kementrian Kesehatan RI

Daryanto. (2017) Hubungan Karakteristik Klien , Keluarga dan Stigma dengan dukungan Keluarga pada Klien Harga Diri Rendah, Jurnal Ilmiah Unbari Jambi Vol.2 Maret 80-93.

Daryanto \& Within K (2020) Daya Tilik Diri, Harga diri dan Stigma Diri serta Kualitas Hidup Pasien Skizofrenia di Poliklinik RSJ Jambi, Jurnal Ilmiah Unbari Jambi Vol 20 Februari 217-224

Friedman, M. (2010). Keperawatan keluarga teori dan praktek $5^{\text {th }}$ ed. Jakarta: EGC

Prabowo, E (2014). Konsep \& Aplikasi Asuhan Keperawatan Jiwa. Yogyakarta: Nuha Medika

Kementerian Kesehatan Republik Indonesia., (2014). Permenkes RI nomor 75 tahun 2014 tentang puskesmas. Jakarta: Kemenkes, R.I.

Kementerian Kesehatan Republik Indonesia., (2014). Permenkes RI nomor 18 tahun 2014 tentang Kesehatan Jiwa. Jakarta: Kemenkes, R.I.

Kementerian Kesehatan Republik Indonesia., Peran Keluarga Dukung 
Kesehatan Jiwa Masyarakat, dipublikasikan 6 oktober 2016 https://www.kemkes.go.id/article/prin t/16100700005/peran-keluargadukung-kesehatan-jiwa$\underline{\text { masyarakat.html }}$

Notoatmodjo, S., (2012). Ilmu perilaku kesehatan kesehatan. Jakarta: Rineka Cipta.

Nurbani., (2009). Pengaruh psikoedukasi keluarga terhadap masalah psikososial ansietas dan beban keluarga dalam merawat pasien stroke. Tesis S2 FIK UI: Tidak dipublikasikan.

Widyanto Faisalaso Candra ., 2014. Keperawatan Komunitas dengan Pendekatan Praktis. Yogyakarta: Nuha Medika 